\title{
SANTA EVITA : INTERTEXTO E PARÓDIA
}

http://dx.doi.org/10.11606/issn.2237-1184.v0i25p53-70

\section{RESUMO}

Este artigo tem por objetivo demonstrar que a estrutura do discurso em Santa Evita (1995), de Tomas Eloy Martinez, é elaborada a partir de um intertexto paródico com o novo jornalismo norte-americano ou romance-reportagem, produzido nas décadas de 1960 e 1970. A análise tem por base, principalmente, o conceito de metaficção historiográfica de Linda Hutcheon e a conceituação de Rildo Cosson a respeito do romance reportagem.

\section{ABSTRACT}

The aim of this article is to demonstrate that the structure of the discourse in Santa Evita (1995), by Tomas Eloy Martinez, is elaborated from a parody intertext with the new American journalism or novel-reportage, produced in the 1960s and 1970s. The analysis is mainly based on Linda Hutcheon's concept of historiographical metafiction and Rildo Cosson's conceptualization of the novel.
Jane Christina Pereira

Instituto Federal de Brasília (IFB)

\section{PALAVRAS-CHAVE:}

Novo romance histórico Hispano-americano.

Santa Evita.

Metaficção.

Romance reportagem.

Intertexto.

Paródia.

\section{KEYWORDS:}

New historical HispanicAmerican novel.

Santa Evita.

Metafiction.

Novel reporting.

Intertext.

Parody. 


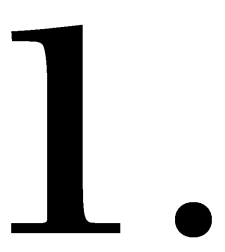

\section{O Novo romance histórico hispano-americano:} paródia e metaficção

O que os críticos hispano-americanos chamam de novo romance histórico, Linda Hutcheon denomina metaficção historiográfica. Parecem ser válidas ambas as denominações. Para justificar a escolha do termo, a estudiosa canadense afirma que a metaficção historiográfica incorpora a autoconsciência teórica sobre a história e a ficção como criações humanas, que passa a sustentar a reelaboração dos conteúdos e das formas do passado.

Diferente de Seymour Menton, que estabelece categorias bem definidas para a classificação dessa nova manifestação literária ${ }^{1}$, a autora canadense procura traçar uma teoria do pós-modernismo, a partir de questões levantadas pela metaficção historiográfica, como a intertextualidade stricto senso (paródia, citação, colagem etc), a referência, as estratégias de representação, a forma narrativa, a relação entre o fato histórico e o acontecimento empírico, a problematização do conhecimento histórico, entre outros.

Segundo Hutcheon, a metaficção historiográfica necessita demarcar as continuidades aceitas como pressuposto na narrativa ocidental: influência, tradição, evolução, desenvolvimento, origem e realiza tal processo através do uso e do abuso dessas continuidades ${ }^{2}$. Além disso, esse tipo de escrita sugere a constante relevância da dicotomia ficção/história, mesmo que essa seja uma oposição problemática. Para ela, esses romances instalam e depois indefinem a linha de separação entre ficção e história.

Outra característica desse tipo de romance é privilegiar duas formas de narração: os múltiplos pontos de vista ou o narrador onipotente. Em substituição a esse tipo de onisciência, quem se apresenta no romance é um "narrador-testemunha" que ora relata história, ora cede lugar às entrevistas, reafirmando estruturalmente o caráter provisório das versões sobre Evita. A partir dessa postura, a limitação e a subjetividade do narrador vem à tona.

\footnotetext{
${ }^{1}$ MENTON, Seymour. La nueva novela histórica de la América Latina-1979-1992. México: Fondo de Cultura Económica, 1993.

${ }^{2}$ HUTCHEON, Linda. Poética do pós-modernismo: história, teoria, ficção. Rio de Janeiro: Imago, 1991.
} 
Trata-se, aqui, da figura histórica, Evita Perón, que na narrativa, Santa Evita, de Eloy Martínez é a personagem principal de quatro histórias interligadas, aparentemente de forma despretensiosa, mas que se configuram em uma simbiose narrativa. A primeira trama desvela a história do destino errante do cadáver embalsamado de Eva Perón. A segunda narrativa trata da história de Evita viva, desde sua origem provinciana até a sua performance política e sua morte esplendorosa aos trinta e três anos de idade. A terceira narrativa descreve a história de militares, vinculados ao Serviço de Inteligência do Exército, que deveriam manter o cadáver embalsamado de Evita a salvo de todos os grupos que desejavam resgatá-lo. O coronel Carlos Eugenio de Moori Koening, um personagem atormentado, é que tem a missão de esconder o cadáver e torná-lo um defunto comum. O quarto enredo é sobre o próprio autor, um personagem obsessivo pela vontade de recuperar uma história do seu país, que parece inverossímil.

Além do caráter provisório de suas narrativas, as metaficções historiográficas também se diferenciam pela sua estrutura que recusa a linearidade. Essa proposta de não aceitação de uma estrutura contínua se deixa ver na aparente desestruturação da narrativa de Eloy Martínez. Em Santa Evita, o narrador opta pela narrativa descontínua e a sobreposição temporal. Os quatro relatos se entrecruzam, em um discurso marcado por rupturas e lacunas, até desembocarem num final provisório e aberto. Essa tendência ao não fechamento da narrativa é abordada por Hutcheon (1999, p. 86), quando demonstra que na estética pós-moderna não há lugar para a resolução, só para a problematização: as repostas são sempre provisórias e contextualmente determinadas ${ }^{3}$.

O romance pós-moderno confere uma visão dialógica do passado, apresentando várias interpretações para os mesmos fatos. Em Santa Evita, o autor simboliza a provisoriedade e a heterogeneidade das versões sobre o passado por meio da multiplicação das cópias do corpo de Evita.

Dessa forma, parodiando o romance-reportagem, que tende ao relato unilateral do fato acontecido, o narrador, em Santa Evita, relata as várias versões do mito, acomodadas em várias narrativas, ou seja, ele absorve o código técnico-formal do romance-reportagem e o transforma parodicamente em romance. Esse jogo de contrastes dá abertura para uma perspectiva bastante instigante: o modo de pensar o mundo (metaficção historiográfica) torna-se mais importante do que os fatos pensados (romance-reportagem), os quais têm que ser pensados em sua essência histórica.

A estrutura formal desses tipos de escrita se apresenta, simultaneamente, correlacionada a elementos do contexto histórico-cultural

${ }^{3}$ Ibidem, p. 86. 
que a produziram e o processo de paródia possibilita a distinção entre o código ideológico que perpassa ambos os gêneros.

Sobre as relações entre a literatura e a história, Eloy Martínez (1996) constata que as fronteiras entre romance e história são cada vez mais tênues, contudo resolve o impasse dialogando com a história e não com o pressuposto que o processo estilístico influencia na participação do receptor. ${ }^{4}$ O trabalho estético de Eloy alerta para as implicações da relação entre sujeito e objeto e entre escrita e ideologia.

Ao analisar o novo jornalismo dos anos 1960/1970, que tinha a verdade factual como base para sua denúncia social, Eloy Martínez afirma que, vinte anos depois, escrever já não é se opor aos absolutos porque numa sociedade livre, onde o poder homogêneo está desestabilizado, não há absolutos. O que sobreviveu, explica o escritor, foi um vazio "que começa a ser preenchido, não por uma versão que se opõe à oficial, mas sim por várias versões, ou por uma versão que vai mudando de cor segundo quem a vê". ${ }^{5}$ Reitera sua argumentação, dizendo que "estabelecer a verdade em termos absolutos é uma empresa quase impossível. A única verdade possível é o relato da verdade (relativa, parcial) que existe na consciência e nas buscas do narrador"6.

Diferenciando-se de muitos romancistas que tentaram reconstruir a imagem da Argentina ideal, em detrimento de um país real, ou daqueles que se opuseram ao poder autoritário, Eloy Martínez busca, em Santa Evita, recuperar e reconstruir o imaginário e as tradições culturais da comunidade:

Levei anos para chegar a estas dobras do meio em que agora estou. Para que ninguém confundisse Santa Evita com O romance de Perón, escrevi entre os dois um relato sobre um cantor de voz absoluta em guerra com sua mãe e uma tribo de gatos. Dessa guerra passei a outras. Reaprendi a escritura, meu ofício, com febre adolescente. Santa Evita ia ser um romance? Eu não sabia nem queria saber. Tudo me escapava: as tramas, a rigidez dos pontos de vista, as leis do espaço e do tempo. As personagens ora conversavam com voz própria, ora com voz alheia, só para me explicar que o histórico nem sempre é histórico, que a verdade nunca é aquilo que parece. Levei meses para amansar o caos. Algumas personagens resistiram. Entravam em cena durante umas poucas páginas e retiravam-se do livro para sempre: acontecia no texto o mesmo que na vida. Mas quando eles partiam, Evita já não era a mesma: tinha chovido sobre ela o pólen dos desejos e das lembranças alheias. Transfigurada em mito, Evita vira milhões. ${ }^{7}$

\footnotetext{
${ }^{4}$ ELOY MARTÍNEZ, T. Santa Evita. São Paulo: Cia. das Letras, 1996a.

${ }^{5}$ ELOY MARTíNEZ, T. "Ficção e história: apostas contra o futuro". O Estado de São Paulo, 5 out. 1996, p. 10. b.

${ }^{6}$ Ibidem, p. 11.

${ }^{7}$ ELOY MARTÍNEZ, op. cit. p. 56-57. a.
} 
De acordo com Hutcheon, os romances pós-modernos usam, de forma paródica, as convenções da literatura popular e de elite para, então, contestar de dentro seus próprios processos. O discurso híbrido de Santa Evita atesta a argumentação de Hutcheon, com a utilização de recursos múltiplos como os discursos da história, da literatura, do cinema, do jornalismo, mas de forma paródica: em Santa Evita, contam-se fatos fictícios como se fossem reais, empregando a pretensa neutralidade e objetividade da linguagem jornalística. Nesse processo paródico, expõe-se, no relato, o "subjetivo, a textualidade das fontes, levando em conta as redes sociais, políticas, musicais, visuais que estão tecendo uma trama com o tempo histórico narrado, para depois mostrar essas redes junto ao texto, onde se as possa ver".

Com esse procedimento, Santa Evita desconstrói a aura de veracidade e seriedade que o romance-reportagem pretende obter, problematizando o fato de que é um discurso que interpreta outro discurso. Como o diálogo estabelecido é paródico, em algumas partes o narrador confessa sua descrença na reconstituição verídica da realidade, mas continua no processo jornalístico de relatar:

As fontes em que se baseia este romance são de confiança duvidosa, mas somente no sentido em que também o são a realidade e a linguagem: nelas se infiltraram lapsos de memórias e verdades impuras. Uma das frases mais famosas de Evita revela qual a sua idéia das coisas. Foi pronunciada em 24 de agosto de 1951: "Sou jovem e tenho um marido maravilhoso, respeitado, admirado e amado pelo povo. Eu me encontro na melhor das situações". Apenas uma dessas afirmações não era discutível: a de que era jovem. Tinha trinta e três anos. Nas outras, só Evita acreditava. Seu marido àquela altura estava sob a ameaça de duas conspirações simultâneas e ela mesma, naquela manhã, ouvira dos médicos a notícia de que sofria de anemia perniciosa e que deveria abandonar a atividade pública. Estava na pior das situações. Faltavam onze para sua morte". ${ }^{9}$

Dessa forma, fica claro que as idéias de Eloy Martínez encontram eco na obra de Linda Hutcheon, que sugere que as metaficções historiográficas tentam demonstrar que só existem verdades nos plurais, jamais uma só Verdade, e raramente existe a falsidade per se, apenas as verdades alheias.

Assim, no romance de Eloy, as várias versões sobre Evita - narradas sob forma de depoimentos, relatos fictícios, narrativas baseadas em documentação histórica e em fontes fictícias, entre outras - são por vezes contraditórias. Dessa forma, o narrador desautoriza qualquer pretensão de inferir legitimidade a apenas uma versão.

\footnotetext{
${ }^{8}$ Ibidem, p. 32.

${ }^{9}$ Ibidem, p. 124. a. 
O romance é permeado por intertextos históricos, literários, cinematográficos, que se encontram disseminados no discurso, sendo reelaborados de forma paródica, para comprovar o valor e também a limitação da forma inevitavelmente discursiva de todo nosso conhecimento sobre o passado.

\section{Santa Evita e o romance-reportagem: intertextualidade}

$\mathrm{Na}$ pós-modernidade, intertextualidade refere-se à combinação ou agrupamento de textos de diferentes linguagens, apresentados em um mesmo suporte e à utilização de diferentes linguagens na elaboração de uma mensagem textual ou discursiva, visando à produção de sentidos prédeterminados no público que interage com ele.

Entretanto, uma das preocupações fundamentais na obra do filósofo da linguagem Mikhail Bakhtin foi a análise da estrutura textual como um elemento construído e elaborado através de outras linguagens, outros textos, outros discursos, seja qual for sua época, cultura ou momento histórico. Com esse postulado, Bankhtin inaugura um novo ponto de vista acerca da linguagem como uma expressão essencialmente condicionada pela presença do "outro". Essa relação de diálogo entre inúmeros textos, que ele veio denominar de dialogismo, seria uma das características básicas de qualquer discurso. Uma das categorias que fazem parte desse conceito de dialogismo desenvolvido por Bakhtin seria o princípio da intertextualidade. Esta seria, portanto, a incorporação de um texto em outro, seja reproduzindo o sentido incorporado ou transformando-o.

A intertextualidade, como recusa à pontuação final no universo infinitivo do espaço cibernético, permite a desorganização da ordem da narrativa, da ilusão realista do significado e da continuidade da história.

O diálogo entre o romance-reportagem e Santa Evita é estabelecido por uma intertextualidade que não se dá de uma forma "harmônica", pois considerando-se a importância das funções da técnica jornalística no romance, tem-se a configuração de uma composição contraditória em sua essência, já que esta obra não segue um enredo baseado na veracidade dos fatos, como faz o romance-reportagem. O próprio Eloy Martínez declara essa estratégia:

Em obras como A Sangre Frio, de Truman Capote, The fight, de Normam Mailer, O Relato de um Náufrago, de Gabriel Garcia Márquez, se contava um fato real com a técnica do romance. Em Santa Evita o procedimento narrativo é exatamente inverso: contam-se fatos fictícios como se fossem reais, empregando algumas técnicas do jornalismo. ${ }^{10}$

${ }^{10}$ Ibidem, p. 01. a. 
Esse recurso vem validar sua constatação de que as fronteiras entre romance e história estão cada vez mais diluídas, mas resolve o impasse dialogando com a história não com verdade, mas como cultura, como tradição. Ao recriar em seu romance um ícone do passado, como Eva Perón, a partir do resgate do imaginário e das tradições argentinas, o autor demonstra que esse ícone é uma construção, expondo a natureza discursiva de suas referências culturais, sociais e historiográficas.

Eloy demonstra em seu ensaio que todo conhecimento do passado é discursivo, relativizando o conhecimento histórico, mas, ao mesmo tempo, acaba por problematizá-lo, ao questionar o significado do histórico e do fictício num país como a Argentina, onde seus líderes se mostram "consumados atores", e a história se confunde com a ficção. Dessa forma, reinstaura o paradoxo da representação fictícia da história:

Se este romance se parece com as asas de uma mariposa - história da morte fluindo para frente, a história de uma vida avançando para trás, escuridão visível, oxímoro de semelhanças -, também há de se parecer comigo, com os restos do mito que fui caçando pelo caminho, e com o que Ela era, com os amores e ódio do nós, com o que foi minha pátria e com aquilo que ela quis ser mas não pôde. Mito é também o nome de um pássaro que ninguém pode ver, a história significa busca, indagação: o texto é uma busca do invisível, ou a quietude do que voa. ${ }^{11}$

Essa posição crítica ataca o discurso do romance-reportagem, pois este reproduz verdades convencionalizadas pelo homem, o que acaba mudando a compreensão do mundo, eliminando assim, a possibilidade de um conhecimento "autêntico", ou melhor, totalmente subjetivo. Secularizada, a obra não pode mais ser dotada de um significado e de um valor que não seja o estabelecido pelo leitor no processo de recepção. Na literatura, as mudanças trazidas pela modernidade atingiram, em cheio, o triângulo que interpunha obra, autor e leitor em um circuito fechado e isolado, porque a obra mostrouse aberta a múltiplas conexões com o fora do texto. Sobrevivendo aos tempos de massificação, o objeto artístico perdeu sua aura, mas manteve às avessas o valor da autenticidade, com a afirmação da leitura como um processo diferenciado e individual, que depende da experiência e historicidade de cada leitor.

Portanto, a intertextualidade não é apenas um elemento, um recurso estilístico; ela passou a ser verdadeira dominante estética na literatura e nas artes de uma forma geral. Essa incorporação de "diversos passados" vem sendo extremamente criticada pela maioria dos teóricos marxistas da

${ }^{11}$ Ibidem, p. 56. a.

59| ENSAIOS 
atualidade que veem nessas colagens apenas ausência de historicidade. Ou seja, o passado seria resgatado não pelo seu valor histórico, mas sim pela incapacidade de representação da própria existência corrente. Por outro lado, as colagens intertextuais na contemporaneidade funcionam como um processo poético que vêm criar um espaço textual múltiplo no qual a obra passa a ser entendida, essencialmente, por meio dessa abertura histórica, resultado do cruzamento dos vários códigos, estilos e linguagens existentes na cultura contemporânea.

Dessa forma, fiel ao conceito de metanarrativa historiográfica, Santa Evita não constrói essa convenção, nem aponta respostas verdadeiras, apenas problematiza os fatos. O autor transfigura em outra coisa o mundo que já é. Fazendo com que as coisas que existem, as que já foram ou não são, sejam como quer que sejam. O que ele promove então, nesse romance, com cara de relato, é a transfiguração das coisas do mundo em outras; ou também um processo de Alquimia. O único modo de se transmitir o conhecimento é através do relato, só o que se narra se compreende. Desde a Bíblia ou O livro dos mortos, dos egípcios, tudo é relato, inclusive a fé.

O romance aponta que somente a partir da contradição é que se pode visualizar a "presença do passado". É, portanto, uma obra que trata da relação entre fato e verdade, como tema central do problema na medida em que nela proliferam os depoimentos, documentos, apesar de, contraditoriamente, a própria estrutura profunda do livro não apresenta estes recursos como meios que pretendem encontrar a veracidade dos fatos.

Santa Evita estrutura-se num jogo de contradições, no qual a possibilidade (prática) de conhecimento da verdade é também a consciência (teórica) de sua precariedade. Segundo Hutcheon,

A teoria e a prática também se entrecruzam em outra área de contestação: desta vez, a contestação às noções de continuidade e tradição. A metaficção historiográfica também tem a necessidade foucaultiana de desmascarar as continuidades que são admitidas como pressupostos na tradição narrativa ocidental, e o faz usando e depois abusando dessas mesmas continuidades... Seja histórico, teórico ou literário, o discurso é sempre descontínuo, apesar de se manter unido por regras se bem que estas não sejam transcendentes. ${ }^{12}$

Tal perspectiva encontra respaldo no intertexto paródico com o romance-reportagem, detectado em Santa Evita, pois ao invés de esconder os nós da construção narrativa como faz o romance-reportagem, o romance de Eloy Martinez os expõe em todo o momento, sem a intenção de encobrir com uma lógica estrutural as verdades que quer desconstruir.

\footnotetext{
${ }^{12}$ HUTCHEON, op. cit. p. 133.
} 
Essa contradição presente em Santa Evita descende das estratégias do pós-modernismo, cuja atuação, segundo Hutcheon, "ocorre na medida em que procura subverter, sem a pretensão de ser um novo paradigma, as convenções, apesar de servir como marco na luta para o surgimento de algo novo". ${ }^{13}$

Nesse sentido, nem o discurso da própria obra escapa ao questionamento, uma vez que se reconhece também como uma convenção dotada de parcialidade, a não ser pela demonstração de consciência dessa parcialidade, que vem totalmente explícita. Sob tal perspectiva, o diálogo entre Santa Evita e o romance-reportagem ocorre por meio de uma intertextualidade de índole pós-moderna, que instaura as técnicas da reportagem, apenas para subvertê-las:

No começo eu pensava: quando eu conseguir juntar os pedacinhos daquilo que um dia transcrevi, quando os monólogos do cabeleireiro ressuscitarem, então eu vou ter a história. E, de fato, a tive, mas era letra morta. Depois perdi muito tempo catando aqui e ali os fósseis do que aconteceu no Cabildo Abierto. Escavei nos arquivos dos jornais, assisti aos documentários da época, ouvi as gravações do rádio. A mesma cena se repetia: Evita sem saber como se safar do amor cego na multidão, aproximando-se, afastando-se; Evita implorando que não lhe deixassem dizer o que queria, que não mais calassem seu dizer. "Não aprendi nada, não acrescentei nada. Naquela montanha inútil de documentos, Evita nunca era Evita". ${ }^{14}$

Se a verdade de um fato é possível para os escritores do romancereportagem, para Eloy Martinez só é possível o discurso de uma verdade que mora na consciência de quem narra, por isso, ao contrário da postura dos escritores de romance-reportagem, Eloy durante toda a narrativa se declara um mediador parcial, subjetivo, limitado que quase nunca ultrapassa o limite de suas vivências. Nessa perspectiva, o autor de Santa Evita reflete, em seu ensaio: "Quanto mais nitidamente um escritor vê o horizonte do que não sabe, tanto maior intensidade pode por no que sabe. [...] Em Santa Evita decidi encarar o desafio de verossimilhança". ${ }^{15}$

O projeto do romance-reportagem de atacar a falsa verdade do poder com sua verdade, segundo Eloy Martinez, foi ultrapassado pela descentralização do poder, além de não ser capaz de abarcar as ressonâncias que a realidade dos latino-americanos produz: "Na tradição cultural da América Latina, nada nunca é o que parece. Nada poderia jamais ser o que parece, porque a realidade se move em ritmo vertiginoso: os valores, as

\footnotetext{
${ }^{13}$ Ibidem, p. 21.

${ }^{14}$ Ibidem, p. 84-85. a.

${ }^{15}$ ELOY MARTÍNEZ, op. cit. p. 11. b. 
fortunas, os mitos. O que ontem estava aqui, hoje está em outra parte, ou não está". ${ }^{16}$

O jornalista e escritor Eloy Martinez transita numa zona de penumbra, segundo definição própria. Nunca se sabe ao certo o que é real e o que é inventado nas histórias que escreve. Sua literatura é marcada por duplos e espelhos, como nos contos de Jorge Luís Borges, que multiplicam as imagens da realidade e da ficção em narrativas mirabolantes. Porém, a realidade, segundo Eloy Martinez, não é mera inspiração, e sim uma instância complementar à sua obra.

O resultado de um trabalho demorado pode ser visto no extremo apuro de uma linguagem que é, sobretudo, protagonista. A história é forte sem dúvida, mas o estilo de Eloy Martinez é o que tempera tudo isso e constrói um relato para além do perfil de simples romance-reportagem. Ele revela um estilo preciso, que consegue aliar a objetividade a uma curiosa adjetivação bem ao gosto da prosa hispano-americana, sem exageros.

Com o tratamento paródico dado às técnicas jornalísticas que compõem o romance-reportagem, as quais prevêem uma visão unilateral e verídica do fato, Eloy Martinez demonstra as várias versões sobre a história de Evita Perón e o faz num intuito de converter a verdade em vazio. Numa apropriação antropofágica das técnicas do romance-reportagem, Santa Evita desconstrói parodicamente a objetividade, problematizando sua construção calcada numa visão onipotente da verdade e se constrói sob uma subjetividade exorável que estrutura, na verdade, qualquer narrativa.

Nesse contexto, Eloy não aceita, também, o conceito de romance histórico que se refere a histórias que ocorreram antes de nosso nascimento, ou pessoas que não são nossos contemporâneos. Eloy Martinez mente, e mais sobre personagens que estão vivos. O relato de histórias sobre seres que estão vivos constitui um avanço e ao mesmo tempo uma transgressão do romance histórico. Trata-se de mitificações plenas da realidade. Os seres vivos possibilitam a recriação da realidade tal como poderia ser, tal como não foi. É a reflexão, o trabalho criativo sobre o que poderia ser. Na lógica do próprio país, Argentina, está sempre à idéia, tão forte que permeia a identidade dos argentinos, dos países que deviam ser e não puderam. Nesse romance, estão os personagens que na realidade histórica puderam ser e sem embargo não foram. Há em Santa Evita um desmascaramento da história e dos personagens da história.

$\mathrm{Na}$ intertextualidade, realizada pela paródia, o outro texto está explícito, mas obviamente já não é o mesmo. Nesse jogo em que o sério e irônico, a paródia permite a reflexão sobre essas questões sem formular respostas, ou seja, o que acontece aqui não é um movimento dialético, visto

${ }^{16}$ Ibidem, p. 10. b. 
que não há uma síntese, mas sim a convivência (na mesma obra) dos pólos opostos: a contradição.

Segundo Bakhtin, a carnavalização é o processo de dessacralização da cultura oficial, que tem seus valores invertidos com a instalação de um universo carnavalesco, onde se rebaixa o que é sublime, torna-se cômico o que é sério. ${ }^{17}$ Tal processo paródico permite visualizar a dimensão da futilidade de princípios sobre os quais a cultura dominante está sustentada e sua ideologia implícita.

Segundo Eloy Martinez, em 1960 e 1970 as certezas absolutas, posições definidas, questionamentos políticos e subversões contra o poder ou submissões ao poder comandavam os exercícios narrativos da história e do romance num clima no qual os conceitos contrastantes eram verdades e mentira. Impulsionado pela justiça, o romance mostrava que a verdade não pertencia mais ao poder. Entretanto, importantes escritores latinoamericanos, que escreveram nesse período deixavam claro a recorrente manipulação da história oficial. Para esses autores, não existem arquivos confiáveis, pois "as instituições podem construir, com seus documentos, uma realidade servil a seus interesses, que é tão falsa quanto à das fábulas". ${ }^{18}$

Balizada pelo procedimento paródico, a poética de Santa Evita apresenta os processos de construção da verdade unilateral da cultura oficial que o romance-reportagem quis representar. Esta manifestação literária adotou o estilo jornalístico, que exige clareza de raciocínio, de modo a separar, no fato objetivo, o que é essencial do que é acidental, e ainda, fazer o comentário justo, induzindo o leitor a compreender bem os acontecimentos. Em Santa Evita é utilizado também o estilo jornalístico, mas ao invés de trazer ao leitor a compreensão do fato objetivo, apresente-lhe a problematização do fato. Na obra de Eloy Martinez, o narrador utiliza as técnicas do jornalismo, mas não acredita em seus métodos estruturais, ao contrário debocha deles; instaura um clima de incerteza que permeia toda a narrativa, mesmo apresentando todas as fontes convencionais que compõem um relato verídico.

$\mathrm{Na}$ construção do romance, Eloy mistura humor, fatos e ficção ao contar o périplo do cadáver de Eva Perón:

O coronel Carlos Eugenio de Moori Koening estava na Escola de Inteligência do Exército dando sua segunda aula sobre a natureza do segredo e os usos boato. "O boato", dizia "é a precaução que os fatos tomam antes de se tornarem verdade". Havia citado os trabalhos de William Stanton sobre a estrutura das sociedades secretas chinesas e lições do filósofo boêmio Fritz Mauthner sobre a insuficiência da linguagem para dar conta da complexidade do mundo real. Mas agora concentrava-se sua atenção no boato. "Todo boato é inocente por

\footnotetext{
${ }^{17}$ BAKHTIN, M. Questões de literatura e estética. 4ª ed. São Paulo: Unesp/Hucitec, 1998.

${ }^{18}$ Ibidem, p. 10. b.
} 
definição, assim como toda verdade é culpada porque não se deixa contaminar, não pode ser passada de boca em boca"19

Eloy acrescenta ao corpo de Evita outra tatuagem da escrita, porque sente que essa cerimônia não tem nada a ver com a necrofilia, mas sim com a carne viva das fantasias argentinas. Todo romance e todo relato fictício são um ato de provocação, porque tratam de impor ao leitor uma representação da realidade que lhe é estranha. Nessa provocação há um eu que se esforça por ser ouvido, um eu que trata de perdurar narrando se a si mesmo.

Duas frases são emblemáticas na vertiginosa trajetória de Eva Perón. A primeira teria sido pronunciada em 16 de janeiro de 1944, quando ela não passava de uma atriz medíocre de rádio. Naquele dia, o coronel Juan Domingo Perón, então ministro do Trabalho, participava, no ginásio do Luna Park, em Buenos Aires, de uma cerimônia pelas vítimas de um terremoto. Aproveitando a ocasião, Evita teria se aproximado e dito: "Coronel, obrigado por existir". Começava ali uma relação amorosa que marcaria tragicamente a história da Argentina. A outra frase - "Voltarei e serei milhões" - Evita teria dito no papel de "rainha dos descamisados", já consumida pelo câncer que a mataria em 1952. Repetidas em inúmeros escritos sobre sua vida, essas frases, na verdade, jamais foram pronunciadas. A constatação é do próprio escritor, para quem a história da América nasce como uma ficção, nas quais relatos fantasiosos se transformam em verdades oficiais. Nada é o que parece ser, porque na realidade, acontecimentos podem apresentar um ritmo alucinante. Por isso, ao tentar reconstruir o itinerário do corpo da mulher de Perón, entre 1955 e 1974, Eloy Martinez escreveu o livro Santa Evita, oscilando entre a reportagem, a história e a ficção.

Apesar disso, Santa Evita nasceu de uma busca pela verdade factual, quando três oficiais da Inteligência do Exército argentino procuraram o escritor para corrigir detalhes da versão que ele dera num livro anterior ${ }^{20}$, ao périplo do corpo de evita. Um corpo que assombra o país, desde 1955, quando um golpe militar derrubou o general Perón. O cadáver embalsamado da primeira-dama foi retirado por militares da sede da CGT, onde era ocultado como uma deusa. Os novos donos do poder decidiram dar-lhe "uma sepultura cristã", porque temiam que o cadáver fosse capturado por peronistas e convertido num troféu. Nesse caso, calculavam os generais, as massas poderiam incendiar o país.

O coronel Carlos Eugênio de Moori Koening, encarregado de enterrar Evita num cemitério portenho, não consegue evitar a sedução "daquela mulher", a inominável, a quem chamava de égua, potranca e vadia. Não por acaso, o coronel acaba seus dias alcoólatra enlouquecido e clamando pela morte.

Impedido de ser enterrado, numa série de acontecimentos intrigantes, o cadáver vai sendo alojado em edifícios, carros, um cinema e até na casa de um

\footnotetext{
${ }^{19}$ Ibidem, p. 16-17. a.

${ }^{20}$ O romance de Perón (1985) 
capitão. A maldição de Evita começa a baixar sobre seus algozes. A cada translado, flores e velas aparecem, misteriosamente, durante a noite. Obra do Comando de Vingança, pensam aos militares. No cinema, a filha do dono brinca com a múmia como se ela fosse uma boneca, a quem chama Pupê. O capitão que abriga Evita, no sótão de sua casa, acaba matando sua mulher. Nunca se soube se ele a confundiu com um ladrão ou se a esposa foi assassinada por ter descoberto a mórbida paixão do marido pelo mito embalsamado.

Em 1957, Eva Perón finalmente embarca, sob nome falso, para ser enterrada em Milão. Ao chegar a Gênova, o caixão onde estava Evita é confundido com uma caixa que trazia do Brasil pertences do compositor Arturo Toscanini e, por isso, é recebido com acordes da Aída, de Verdi, para desespero do oficial argentino que acompanhava o corpo. O círculo de horrores estava longe de terminar. Em 1971, Evita é devolvida a Perón, então exilado em Madri. Dois anos depois, o cadáver volta para a Argentina e é enterrado na quinta de Olivos. Em 1976, a ditadura militar ordena sua transferência para o cemitério da Recoleta. No trajeto, um suboficial morre de ataque cardíaco e quando seu acompanhante freia a camionete, os dois soldados que guardavam a múmia morrem ao cair sobre as baionetas.

Além da história da peregrinação do corpo de Evita, o romance traz ainda o roteiro de escrita do narrador e a biografia de Evita, num estilo adotado nos romances-reportagens. Entretanto, Eloy Martinez deixa de seguir o rastro da exatidão e da veracidade, características dos romancesreportagens, para privilegiar a transformação de Maria Eva Duarte de Perón em Santa Evita. Assim, a narrativa centra-se na imaginação autoral e popular, povoando-a de tipos históricos e alusões ao mito em torno da vida de Evita:

Portanto, explicitar a subversão que os mecanismos utilizados pelo romance-reportagem sofrem em Santa Evita é a melhor forma de entender a estrutura profunda desta obra, que redimensiona o mito subvertendo-o:

Não contaria Evita como malefício nem como mito, iria contá-la tal como a sonhara: como uma mariposa que batia para frente asas de sua morte, enquanto as de sua vida voavam para trás. A mariposa estava suspensa sempre no mesmo ponto, e por isso eu também não saía do lugar. Até que descobri o truque. Não devia me perguntar como se voa ou para quê, mas simplesmente começar a voar. ${ }^{21}$

Diante de toda a discussão já tecida na presente análise, pode-se concluir que a metaficção historiográfica exige um leitor atento, não apenas para o reconhecimento de vestígios textualizados do passado literário e histórico, mas também para a percepção do que foi feito - por meio da ironia - a esses vestígios.

${ }^{21}$ Ibidem, p. 67. a. 
Eloy Martinez não faz a reconstituição da história de evita, mas sim a problematização da possibilidade de fazer denúncia social por meios dos mecanismos utilizados pelo romance-reportagem, ou seja, a partir do documento e da testemunha.

Num contexto posterior aos anos 60/70, cuja regra, em vários países latino-americanos, era a censura aos meios de comunicação e a perseguição a artistas que poderiam simbolizar aquela realidade, a construção fictícia de Evita Perón oferece importantes subsídios ao desenvolvimento das complexidades do "ser real" Maria Eva Duarte Perón. Contrariando, portanto, o romance-reportagem, inteiramente alimentado do "real verídico", Santa Evita caracteriza-se por negar a convenção da veracidade que pontua tal procedimento jornalístico. E por aqui já começa o embate entre a verdade factual, que o romance-reportagem pretende testemunhar, e a verdade da consciência individual procura edificar.

Além do testemunho, outro recurso utilizado pelo romancereportagem é a documentação dos depoimentos e dos fatos relatados como provas materiais de sua efetiva realidade, seja por meio de dados cientificamente comprovados e validados, seja por meio de fotografias e ou de declarações gravadas. O narrador de Eloy Martinez não foge a esta regra: transcreve gravações, anexa documentos, mas evidenciando sua descrença numa verdade retirada desses recursos, ao revelar que documentos pessoais de Evita e Perón seriam propositadamente forjados.

Enquanto o romance-reportagem se acomoda numa teia de faticidade, Santa Evita se estrutura em estratégias de verossimilhança, próprias do texto literário. Como o romance-reportagem é construído, na maioria das vezes, sobre os fatos retirados das manchetes de primeira página de jornal, a verdade que o marca semanticamente, é também factual. Todavia, a teia de faticidade, apesar de utilizar igualmente documentos e outros elementos legitimadores do relato, substitui os meios de controle da subjetividade, por um conjunto de processos narrativos realistas, processos que ocultam ou procuram ocultar sua função. Até porque um romance-reportagem não se contenta em ser factualmente verdadeiro, para ele é fundamental parecer verdadeiro.

O livro Santa Evita, do mesmo modo, quer parecer verdadeiro, mas contraditoriamente, não tenta esconder a subjetividade por trás dos fatos, por isso vai apresentar também todos os processos narrativos realistas, mas com objetivo de mostrar que seus métodos não respondem ao seu propósito, ou seja, revelar através da paródia que há uma discrepância entre conteúdo e forma nos romances-reportagens.

Ao apresentar-se como um texto central, que converge aquilo que Bakhtin chama de polifonia, uma multidão de vozes, Santa Evita parodia o discurso monológico da autoridade, da verdade, que sustentam os procedimentos estéticos utilizados pelo romance-reportagem. Nesse ato de 
auto-reflexividade, Santa Evita confessa-se uma obra de ficção, e recusa a construção do mundo como mimesis como é próprio do romancereportagem. Em vez disso, a obra explicita a sua condição de texto central, que opera a transformação e assimilação de vários outros textos, colocando em destaque o seu processo de construção: a intertextualidade.

Segundo Cosson, A Sangue Frio, de Truman Capote, pode ser apontado pela crítica literária, principalmente a brasileira, como modelo desse modo de narrar caracterizado, principalmente, pelo encontro do jornalismo com a literatura. A razão de tal atitude, afirma o teórico, está na semelhança de propostas e de realizações entre o romance de não ficção americano e o romance-reportagem no Brasil, dentre as quais se destacam a objetividade da linguagem, sempre parajornalística, e a obediência estreita aos fatos, normalmente retirados de uma manchete de jornal e aprofundados pelo autor do livro. Essas e outras semelhanças parecem ter sido suficientes para que a hipótese da origem do romance-reportagem como imitação ou influência do romance de não-ficção ganhasse, por parte da crítica brasileira, a legitimidade de um dado já confirmado.

Se o romance-reportagem é de fato um gênero nascido do discurso literário, sua marca definidora em nível semântico é, sem dúvida, a verdade factual emprestada da reportagem. Assim, o que envolve a significação deste tipo de literatura é a factualidade extremada do relato, transmitida pelo testemunho de uma realidade efetivamente ocorrida. Em relação a esse procedimento, Cosson pontua: "Testemunho que almeja ser e se apresenta mesmo, para além de uma simples versão de algo acontecido, como a verdade última dos fatos". ${ }^{22}$ Dessa forma, a verdade factual se transforma em verdade testemunhal. O testemunho ficcional de fatos não ocorridos em Santa Evita desterra essa premissa.

Para esse mesmo autor, a factualidade do romance-reportagem, apesar de utilizar igualmente documentos e outros elementos legitimadores do relato, substitui os meios de controle da subjetividade por um conjunto de processos narrativos realistas, como recordação, motivação psicológica, validação do discurso, circulação de informações, descrição, localização espacial, registro da fala dos personagens, datação, entidades e referências históricas, utilização de documentos. Tais processos ocultam ou procuram ocultar o caráter arbitrário e subjetivo da sua história. Isso explicaria, por que, no romance-reportagem, convivem lado a lado a escamoteação da subjetividade do narrador, que poderia perturbar a premissa básica de factualidade da narrativa, e a "afirmação peremptória" de uma verdade inteira que não foi, mas precisa ser dita. É, portanto, a partir do desnudamento do real que o romance-reportagem torna explícito o desejo de mudar o mundo

\footnotetext{
${ }^{22}$ COSSON, R. Romance-reportagem: o gênero. Brasília: UnB, 2001, p. 24.
} 
por meio da denúncia social que a verdade, espelhada nos fatos de sua narrativa, evidencia e consuma.

$\mathrm{Na}$ análise de Cosson, a datação nos romances-reportagens é sempre precisa e segura. Em primeiro lugar porque ela é responsável, em grande parte, pela coesão temporal da narrativa. Depois, como é "prática corrente nos romances-reportagens o apagamento do tempo discursivo em favor do tempo da diegese, a datação desta última torna-se uma presença necessária e obrigatória da cronologia narrativa". ${ }^{23}$ Para Eloy Martinez, entretanto, além da data poder ser forjada segundo interesses específicos, o tempo na sua narrativa é interpolado e emoldurado pela concepção cíclica borgeana.

Já em seu "Paradiso", Dante preconizava a insuficiência da linguagem humana para retratar a sua visão do paraíso. Em Santa Evita, essa precariedade é retomada como o ponto crucial da discussão teórica que permeia o livro, sobre a impossibilidade mimética da representação: "[...] as lições do filósofo boêmio Fritz Mauthner sobre a insuficiência da linguagem para dar conta da complexidade do mundo real". ${ }^{24}$

No seu projeto de revigorar o mito do imaginário argentino, Eloy Martinez deixa evidente tal postura: "Aos poucos Evita foi se transformando num relato que, antes de se extinguir, já acendia outro. Deixou de ser o que disse e o que fez para ser o que dizem que disse e o que dizem que fez". ${ }^{25}$

A primeira matriz fictícia do romance é o conto "Esa mujer", de Walsh, evidenciando o vínculo estreito o primeiro e a tradição aberta pelo segundo, o qual explora a tensão e ambigüidade entre ficção e documento. Sobre esse diálogo entre as duas obras, Marisa Navarro (2002), lembra que em Santa Evita, quando o narrador diz: "Neste romance povoado de personagens reais, os únicos que não conheci foram Evita e o coronel", está resgatando este último conto de Walsh, e o expandindo como protagonista. Segundo Navarro, o texto assinala o coronel na entrevista do narrador com sua viúva, estabelecendo uma continuação, muitos anos depois, daquele encontro central em "Esa mujer". A estudiosa salienta que o narrador de Santa Evita e a viúva do coronel são agora os que entrecruzam informações, que acabam girando em torno do conto e o confirmando.

Reiterando o seu estudo, Navarro analisa a duplicação da intersecção entre ficção e jornalismo nos próprios relatos testemunhais de Santa Evita, este que mantém uma conversação com Walsh, tem seu conto retomado e é introduzido em seu capítulo "Poucas horas antes de minha partida". Tal episódio, de acordo com a estudiosa, reforça a confiabilidade histórica de "Esa mujer" e confirma o episódio narrado como verdadeiro.

\footnotetext{
${ }^{23}$ COSSON, R. Romance-reportagem: o gênero. Brasília: UnB, 2001, p. 45.

${ }^{24}$ Ibidem, p. 17. a.

${ }^{25}$ Ibidem, p. 82. a.
} 
Se no conto de Walsh o acesso à verdade, aos fatos tal qual foram e a ilusão de posse do corpo pelo coronel, acabam frustradas, em Santa Evita se dá totalmente por falida a natureza jornalística e a verdade do relato.

Dentro dessa perspectiva que ataca a verdade jornalística do romancereportagem, o capítulo "Contar uma história", se configura explicitamente em cima dessa crítica e a auto-reflexividade se instala integralmente. Nesse processo metalingüístico, a contradição se apresenta num discurso que usa a linguagem jornalística, porém desestabiliza seus mecanismos.

Nesse momento da narrativa, o leitor se vê diante de uma epígrafe que já prenuncia a inevitável interpenetração entre acontecimento e mito, que elaborada pelo imaginário popular resulta num fenômeno cultural e não mais histórico.

Dialogando com a reportagem, o narrador se embrenha no mundo documental, buscando um caminho jornalístico rumo à verdade sobre Evita: "Depois daquele encontro, passei várias semanas em arquivos de jornais. Se a maldição invocada pela viúva era verdadeira, mais cedo ou mais tarde eu deveria encontrar algum fato que a confirmasse". Ao trabalhar nessas investigações, "tecido de redes múltiplas", o narrador titubeia na intenção jornalística do relato e alardeia metáforas, cujas significações ilimitadas desestabiliza a objetividade pretendida:

As almas têm sua própria força da gravidade: são avessas às altas velocidades, ao ar livre, à ansiedade [...] Mas, se por um lado detestam ser deslocadas, as almas também aspiram a que as escreva. Querem ser narradas, tatuadas nas rochas da eternidade. Uma alma que não foi escrita é como se nunca houvesse existido. Contra a fugacidade, a letra. Contra a morte, o relato. ${ }^{26}$

Com essa concepção de que só a arte vence a morte, o narrador coloca seu relato num patamar metafísico, sem abrir a possibilidade para uma possível função social, na qual não acredita. No seu conflito entre a busca pela melhor forma de relatar, se rende à total parcialidade do relato:

Mencionei as teias de conspirações urdidas pelo coronel e seus discípulos da escola de espionagem, sobre mesas de areias coloridas como tabuleiro de xadrez. Nada disso fazia sentido e quase nada sobreviveu nas versões posteriores. Certas frases, em que trabalhei semanas a fio, se evaporaram ao sol da primeira leitura, cortadas pela impiedade de um relato que não precisava delas. ${ }^{27}$

Continuando suas investigações, seja no jornal Democrata, onde encontram um "asséptico relato", ou quando recebe por correspondência um

\footnotetext{
${ }^{26}$ Ibidem, p. 54. a.

${ }^{27}$ ELOY MARTÍNEZ, op. cit. p. 55. a. 
"insólito documento", o narrador vai aos poucos se certificando que a verdade não é possível; só é possível o desejo daquilo que deveria ser: "Naquela época dos grandes recordes, as pessoas estavam cheias de desejos, e Evita cuidava para que todos se cumprissem. Evita era uma enorme rede que saía à caça de desejos como se a realidade fosse um campo de borboletas". ${ }^{28}$

$\mathrm{Na}$ reflexão sobre sua escritura, o narrador fecha o capítulo com uma descoberta estilística:

Não contaria Evita como malefício nem como mito. Iria contá-la tal com o a sonhara: como uma mariposa que batia para frente as asas de sua morte, enquanto as de sua vida voavam para trás. A mariposa estava suspensa sempre no mesmo ponto, e por isso eu também não saía do lugar até que descobri o truque. Não devia me perguntar como se voa ou para quê, mas simplesmente começar a voar. ${ }^{29}$

Assim, o conflito se desfaz: a metaficção não pergunta por quê, apenas conta; sem atacar nenhuma verdade, apenas reinventa a história, revive o mito. O romance de Eloy Martinez reitera as funções de seus relatos testemunhais como escritura desviada, que narra o omitido e oculto pelo jornalismo convencional.

Recebido em 02/10/2017

Aprovado em 31/10/2017

\footnotetext{
${ }^{28}$ Ibidem, p. 56
}

${ }^{29}$ Ibidem, p. 67. 